・编者按・

\title{
中国国家公园建设取得标志性进展
}

\author{
马克平 ${ }^{*}$ \\ (中国科学院植物研究所植被与环境变化国家重点实验室, 北京 100093)
}

\section{A significant achievement in the development of national parks in China}

\section{Keping Ma*}

State Key Laboratory of Vegetation and Environmental Change, Institute of Botany, Chinese Academy of Sciences, Beijing 100093

我国的生态文明建设不断取得新的进展, 令世 人瞩目。习近平总书记在 10 月 18 日的十九大报告中 指出: “我们要建设的现代化是人与自然和谐共生 的现代化, 既要创造更多物质财富和精神财富以满 足人民日益增长的美好生活需要, 也要提供更多优 质生态产品以满足人民日益增长的优美生态环境 需要”。国家公园应该是此等优质生态产品中的典 型代表。2013年召开的中国共产党第十八届中央委 员会第三次全体会议提出建立国家公园体制。十九 大进一步明确“建立以国家公园为主体的自然保护 地体系”。经过近四年的努力, 中国国家公园建设逐 步走向正轨, 进展迅速。在国内外充分调研和总结 国家公园试点经验的基础上，中共中央办公厅和国 务院办公厅于9月26日印发了《建立国家公园体制 总体方案》(以下简称《总体方案》)。《总体方案》 提纲彗领, 简明扼要, 具有很强的指导性和科学性, 在中国国家公园建设进程中具有标志性。全文五千 余字, 在明确国家公园概念的基础上, 从总体要求 (指导思想、基本原则和主要目标)、科学界定国家 公园内涵(内涵、定位、空间布局和自然保护地体 系)、建立统一事权和分级管理体制(统一的管理机 构、分级行使所有权、协同管理机制、监管机制)、 建立资金保障制度(财政投入为主的多元化资金保 障机制和资金使用管理机制)、完善自然生态系统保 护制度(严格保护管理制度、差别化保护管理方式和 责任追究制度)、构建社区协调发展制度(社区共管 机制、生态保护补偿制度和社会参与机制)和实施保
障(组织领导、法律法规、與论引导和督促落实)等 七个方面对如何建设中国的国家公园作出了清晰 的阐述。

为了更好地理解总体方案, 我们特别邀请了几 位深度参与该方案制定工作的专家从不同角度进 行解读。杨锐认为树立正确的国家公园理念, 要强 调生态保护第一、国家代表性和全民公益性, 必须 强化国家公园的“三公”(公有、公管和公正)属性。 “公有”体现所有权属性，“公管”体现管理权属性， 而“公正”则体现伦理学属性。朱春全将中国的国家 公园建设与已经存在的中国国家自然保护地体系 的完善相结合, 指出国家公园是中国自然保护地体 系中的一个新类型, 设立国家公园不是孤立地进行, 也不是完全取代或替代原有的自然保护地类型, 而 是要以此为契机, 制定中国国家公园和其他类型自 然保护地的标准, 按照统一的标准和框架对中国现 有各种类型的自然保护地进行科学的分类和梳理, 建立中国自然保护地管理分类体系。王毅从中国的 国情出发, 强调中国国家公园建设的渐进性, 指出 目前世界上许多国家都建立了自己的国家公园体 系, 并有不少成熟经验, 但也存在多种模式。国家 公园在我国是新生事物, 在创建过程中, 难免存在 认识上、操作上、监管模式上的不同看法。对此, 《总 体方案》坚持实事求是, 力求做好改革过程的衔接, 在国家公园设立、所有权让渡、保护地整合等方面 采取有步骤、分阶段推进的渐进改革方针, 成熟一 个设立一个, 以保障国家公园建设依法科学有序地

* 通讯作者 Author for correspondence. E-mail: kpma@ibcas.ac.cn 
推进。魏钰和苏杨针对我国保护地的通病, 即产权 主体虚置、产权管理不到位、资产化管理与资源化 管理边界模糊等问题, 认为通过总体方案的实施, 有了基于产权归属的事权统一和相应的资金保障, 各利益相关者的责权利才能真正相当，从而让参与 国家公园体制建设的各方在“看齐意识”中获得“道 路自信”，走好国家公园体制建设的全民公益大道; 也希望以国家公园为代表的自然保护地体系能按 此“方”下药一并解决“权、钱”难题。王风春从依法 保障国家公园体制稳步建设角度, 提出完善国家公 园法律法规应该尽快开展的几项工作：一是抓紧评 估现行自然保护区、风景名胜区、文化自然遗产、 地质公园和森林公园等的法律规定和行政规范, 在 法律上确立包括国家公园在内的完整自然保护地 分类体系; 二是加紧研究建立以国家公园法律法规 为核心的自然保护地法律法规框架体系; 三是加快 研究制定有关国家公园的法律法规框架和基本法 律制度体系; 四是加快研究制定有关国家公园的标 准与技术规范体系。

此外, 在落实《总体方案》的过程中还有几点 应该特别重视:

第一, 针对由有关部门和地方政府已经设立的 “国家公园”, 《总体方案》强调, “各地区各部门不 得自行设立或批复设立国家公园。适时对自行设立 的各类国家公园进行清理”。明确审批权限非常重 要, 是保证国家公园质量的重要环节。此外, 需要 明确的是“国家森林公园”、“国家湿地公园”、“国家 沙漠公园”和“国家生态公园”等不是总体方案所指 的“国家公园”。

第二, 中国的国家公园建设背景与其他国家不 同, 是在已经建立了上万个自然保护地的基础上开
始建设的。因此, 如何在现有自然保护地体系的基 础上建立中国的国家公园面临诸多挑战，必须将国 家公园建设与现有自然保护地体系的优化完善相 结合。“对我国现行自然保护地保护管理效能进行 评估, 逐步改革按照资源类型分类设置自然保护地 体系, 研究科学的分类标准, 理清各类自然保护地 关系，构建以国家公园为代表的自然保护地体系”。

第三, 对于中国东部人口密集区的国家公园建 设中如何处理集体土地问题, 《总体方案》在强调 “规范流转”的同时, 也体现了一定的灵活性, “按照 自然资源特征和管理目标，合理划定功能分区，实 行差别化保护管理”。

第四, 在构建社区协调发展制度中, 特别强调 要建立和完善社区共管和社会参与机制。这是现行 自然保护地体系比较薄弱的方面, 应该着力加强。

第五, 《总体方案》强调, 坚持生态保护第一, 坚 持国家代表性，坚持全民公益性。在解释全民公益性 时提到“国民福利的游㮩机会”, 然而, 如果没有好的 旅游设施和服务, “国民福利的游惒机会”很难实现。 因此, 建议在某些国家公园试点区对此进行探索, 总结出可行方案。

第六, 目前国家公园试点区非常重视国家公园 建设, 一般都是地方政府或党委主要负责人兼任管 理机构的一把手。希望在试点结束正式设立国家公 园后, 能够根据管理的实际需要, 明确国家公园的 专职负责人。既有利于国家公园主要负责人全身心 投入管理，又有利于推动地方政府的工作。 